\title{
Spatial distribution of crustacean zooplankton in a large river-connected lake related to trophic status and fish
}

\author{
Wenzhi WEI, ${ }^{1}$ Riming CHEN,${ }^{2}$ Liufu WANG, ${ }^{1}$ Lixia FU ${ }^{1 *}$ \\ ${ }^{1}$ Yangzhou University, College of Animal Science and Technology, 88 South University Road, Yangzhou 225009; ${ }^{2}$ Lake Gaobaoshaobo \\ Fishery Administrative Committee, 732 Middle Yangzijiang Road, Yangzhou 225009, China \\ *Corresponding author: dynamicren@163.com
}

\begin{abstract}
It has been reported that community structure of crustacean zooplankton is related to environment factors and abundance of predacious fishes. Most studies, however were based on observation on independent water bodies, which may complicate the results with uninterested factors. A large river-connected lake has partitioned regions with the characteristics of either a river or a lake albeit allowing exchanging of zooplankton of different regions. Thus, a river-connected lake is an ideal system for studying distribution of crustacean zooplankton and investigating its affecting factors. In this study, 11 stations of a large river-connected lake, Lake Gaoyou, were sampled in all four seasons. Taxonomic diversity and species abundance were recorded and their correlation with environmental factors was investigated. A total of 26 and 22 species of crustacean zooplankton were recorded in the river and lake region, respectively. The abundance of crustacean in the river region was significantly higher than that in the lake region. The relative abundance of calanoids and Bosmina fatalis in the river region was lower than that in the lake region, whereas the abundance of cyclopoids and other cladocera species was lower in the lake region than in the river region. Cluster analysis showed that crustacean assemblages could be divided into two, one cluster grouping all sites from the river region, and the other cluster included all sites in the lake region. According to Pearson correlation and canonical correspondence analysis, the distribution of crustacean was positively correlated with water temperature and chlorophyll a gradient. Chlorophyll a and fish abundance are excellent predictors on spatial distribution of crustacean zooplankton in Lake Gaoyou. Our findings may also help in planning of bighead carp stocking in Lake Gaoyou.
\end{abstract}

Key words: River-connected lake; crustacean zooplankton; trophic status; fish.

Received: January 2017. Accepted: May 2017.

\section{INTRODUCTION}

Aquatic ecosystems are characterized by complex interactions of biotic and abiotic factors (Fisher et al., 2007). Crustacean zooplankton which comprise cladocerans and copepods are one of the most important organisms, because they occupy an intermediate position between microorganisms (microalgae, rotifers, protozoa, and bacteria) and larger organisms (e.g., fish) (Berggren et al., 2014; Sarma et al., 2006). Meanwhile, because crustacean zooplankton often have wide geographical distributions, sensitive to individual stressors, and their morphology are easy to identify (Cairns et al., 1993), factors affecting community structure of crustacean zooplankton have been studied intensively in the last few years. However, most studies were focused on isolated lakes, reservoirs or on the comparison between different water bodies (Degefu and Schagerl, 2015; Pinto-Coelho et al., 2005), so the results may be complicated by other uninterested factors, such as existing species and community structure due to historic reasons.

A river-connected lake, which is usually connected to a river in the upper and lower reaches, undertakes the flood-drainage task with the migration of water exchange and water-level-fluctuation range. A large river-connected lake, which includes river and lake region, i.e., has the characteristics of the river and lake and presents the rich variety of environmental condition. An important function of a river-connected lake is to repair the ecological environment (Ren et al., 2007). Some researchers have carried out a series studies about the water-environment carryingcapacity calculation methods of river-connected lakes (Wang et al., 2015; Yang et al., 2015). Other researchers focused on the cyanobacteria distribution and macrozoobenthic community in river-connected lakes (Liu et al., 2016; Wang et al., 2007). However, little attention has been paid to the spatial distribution of crustacean zooplankton and their correlation with environmental factors in river-connected lakes. River-connected lakes are ideal system for studying spatial distribution, community structure of crustacean zooplankton and its affecting factors. Different from independent lakes, the zooplankton communities in a river-connected lake are connected, so the difference in community structure of crustacean zooplankton must be due to difference in microhabitat only. Studies on spatial distribution of crustacean zooplankton 
and the effects of environment factors on crustacean zooplankton communities in river-connected lakes have great significance in the protection and utilization of the water environment. For example, stocking of filter-feeding bighead carp is often planned based on the distribution data of crustacean zooplankton (Guo et al., 2015).

The factors taken into account were mainly water chemistry, macrophytes and eutrophication (Alexander and Hotchkiss, 2010; Dodson et al., 2005). However, the spatial distribution of crustacean zooplankton is not always related to single environmental factor, and have seemingly contradictory distribution patterns in different water bodies (Hulot et al., 2000). Abundance of fishes also is often claimed to be related to the community structure of crustacean zooplankton (Dzialowski et al., 2013), but few studies really reported empirical data on it due to high expense in collecting all fish in experiment regions.

The middle and lower reaches of the Yangtze River are connected by many rivers and lakes that frequently interact with one another. In present study, Lake Gaoyou including river and lake region, as a typical river-connected lake, was sampled to determine the relationships between abundance and structure of crustacean and environmental factors. The objectives are i) to compare zooplankton species composition between the river and lake region, and ii) to investigate the environmental factors influencing on the abundance and structure of the crustacean zooplankton assemblage in the river region and the lake region of the same lake.

\section{METHODS}

\section{Study area}

Lake Gaoyou $\left(32^{\circ} 42^{\prime}-33^{\circ} 04^{\prime} \mathrm{N}, 119^{\circ} 06^{\prime}-119^{\circ} 25^{\prime} \mathrm{E}\right)$ is the sixth largest freshwater lake in China and covers an area of $674.7 \mathrm{~km}^{2}$, with a mean depth of $1.44 \mathrm{~m}$ and a maximum depth of $2.4 \mathrm{~m}$. It lies in central Jiangsu Province, lower reaches of the Huaihe River and west of the Jing-Hang (Beijing-Hangzhou) Grand Canal with subtropical and monsoon climate (Liu et al., 2016). Water from the Huaihe River contributes $95 \%$ of the total input for the south of Lake Gaoyou via the waterway to the Yangtze River (Li et al., 2007). The river region exists in the south part of Lake Gaoyou and the lake region exists in the north (Fig. 1A). In July, the dominant macrophyte species in the river region is Myriophyllum spicatum (wet weight biomass, $0.4 \mathrm{~kg} / \mathrm{m}^{2}$ ). The dominant macrophyte species in the lake region is Trapa incisa (wet weight biomass, $6.2 \mathrm{~kg} / \mathrm{m}^{2}$ ). Water in river region often is turbid, whereas water in lake region is clear. Another character distinguishing the river region and the lake region is the sediment. The river region has a hard bottom, whereas the lake region has deep soft sediment.

\section{Sampling and physicochemical analyses}

Eleven sampling stations were selected at regular spatial intervals from south to north. The river region included the stations s1, s2, s3, s4, s5, s6 and the lake region
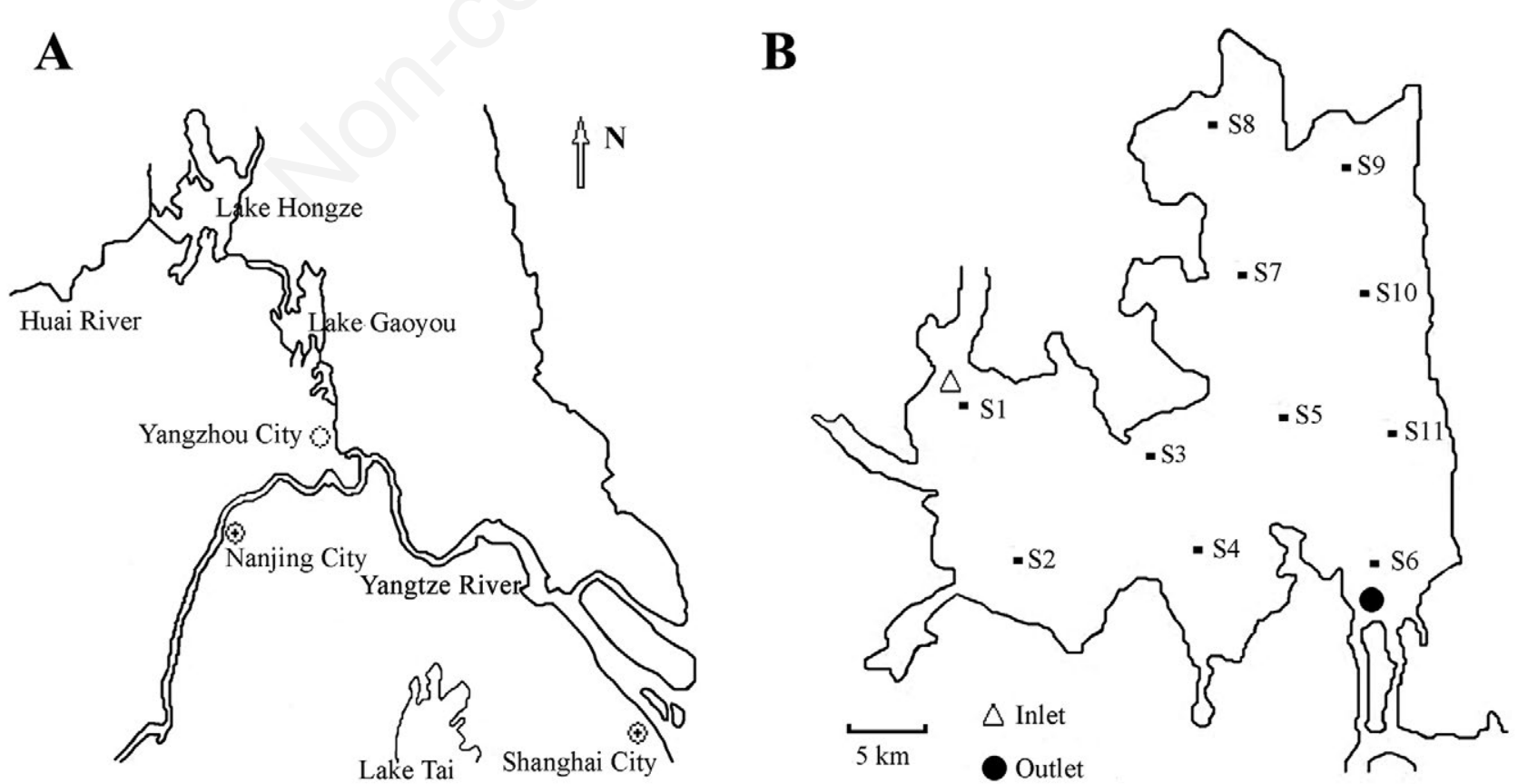

Fig. 1. Maps of (A) location of Lake Gaoyou and (B) 11 sampling stations in the lake. 
included the stations s7, s8, s9, s10, s11 (Fig. 1B). Samples were collected on four seasons: April, July, October in 2013, and January in 2014. Physical-chemical parameters including water temperature (WT), transparency (Secchi disk depth), dissolved oxygen (DO), and $\mathrm{pH}$ were determined in situ below the water surface $(0.5 \mathrm{~m})$. WT and DO were measured using FG4-FK (Mettler Toledo Co., Greifensee, Switzerland), and $\mathrm{pH}$ was measured using FG2-FK (Mettler Toledo Co.). Water samples below the water surface $(0.5 \mathrm{~m})$ were collected in plastic bottles to measure total nitrogen (TN), total phosphorus (TP), and chlorophyll $a\left(\mathrm{Chl} a\right.$; pretreated with $1 \% \mathrm{MgCO}_{3}$ ) according to the Chinese Standard Methods for the Surveys of lake eutrophication (Jin and Tu, 1990) .

\section{Crustacean and fish analysis}

For each station, $50 \mathrm{~L}$ of water was collected at a depth of $0.5 \mathrm{~m}$ using bucket hauls, and the crustacean sampled was filtered through a plankton net (mesh size: $0.064 \mathrm{~mm}$ ) and preserved in $4 \%$ (final concentration) formalin solution. zooplanktonic crustacean were identified based on their morphology (Chiang and Du 1979) and then counted at 40× magnification with an Olympus CX21 microscope. Cladoceran and copepod adults were only considered in this study.

To investigate the fish abundance, water area up to $10.0 \mathrm{ha}^{2}$ was respectively enclosed with polyethylene mesh $(3.0 \mathrm{~cm})$ in the river and lake region in December 2013, and four electronic trawl nets (Direct Current Voltage, $380 \mathrm{~V}, 12 \mathrm{~A}$ ) were trawled simultaneously for 2 hour in the enclosures to capture as many fish as we can.

\section{Data analysis}

An independent-samples t-test was used to compare the difference of physical-chemical parameters and crustacean abundance between the river and lake region using SPSS ver. 15.0 software. The degree of similarity of crustacean zooplankton assemblages among the 11 sites was calculated using the Bray-Curtis similarity coefficient and Ward's method based on the abundance of each species in PCORD (Nanami et al., 2005). Pearson's Correlation Analysis was used to determine the relationships between zooplankton abundance and the environmental variables using SPSS ver. 15.0 software. Additionally, these relationships were confirmed with a canonical analysis, which combines the concepts of ordination and regression using CANOCO 4.5 (ter-Braak and Šmilauer, 2002).

\section{RESULTS}

\section{Physicochemical parameters}

The mean \pm SD values of the physical and chemical composition, and $\mathrm{P}$-values for $t$-tests between the river and lake region were listed in Tab. 1. The WT, DO, pH, or TP determined was not significantly different between the river and lake region $(\mathrm{P}>0.05)$. However, significant difference was detected for TN $(\mathrm{P}<0.05)$, transparency and $\mathrm{Chl} \mathrm{a}(\mathrm{P}<0.01)$ (Tab. 1).

\section{Comparison of fish}

In river region, the three main species were Carassius auratus, Cultrichthys erythropterus and Erythroculter ilishaeformis, but C. auratus, C. erythropterus and Hemiculter leucisculus were the three dominant species in lake region. The fish abundance and total mass of the river region were lower than that of the lake region (Tab. 2).

\section{Species composition and occurrence frequency of crustacean}

In the river region, a total of 26 species of crustacean zooplankton were collected, including 14 species of cladocera (53.85\% of abundance; belonging to 10 genera) and 5 species of calanoida (19.23\%; belonging to 4 genera) as well as 7 species of cyclopoida $(26.92 \%$; belonging to 7 genera); and 10 species (D. leuchtenbergianum, $B$. fatalis, Bosminopsis deitersi, Moina micrura, Sinocalanus

Tab. 1. Mean $\pm \mathrm{SD}$ values for the physical and chemical composition, and $\mathrm{P}$ values for $t$-tests between river region and lake region (95\% confidence interval).

\begin{tabular}{lccc} 
& River region & Lake region & P value \\
Water temperature $\left({ }^{\circ} \mathrm{C}\right)$ & $18.88 \pm 8.87$ & $18.86 \pm 9.11$ & 0.995 \\
\hline Dissolved oxygen $\left(\mathrm{mg} \mathrm{L}^{-1}\right)$ & $8.01 \pm 1.66$ & $8.64 \pm 2.42$ & 0.334 \\
\hline $\mathrm{pH}$ & $7.81 \pm 0.42$ & $8.03 \pm 0.92$ & 0.305 \\
\hline Transparency $(\mathrm{m})$ & $0.38 \pm 0.27$ & $0.77 \pm 0.42$ & 0.001 \\
\hline Total nitrogen $\left(\mathrm{mg} \mathrm{L}^{-1}\right)$ & $0.99 \pm 0.49$ & $0.74 \pm 0.23$ & 0.043 \\
\hline Total phosphorus $\left(\mathrm{mg} \mathrm{L}^{-1}\right)$ & $0.10 \pm 0.06$ & $0.08 \pm 0.04$ & 0.097 \\
\hline Chl $a$ (ug L & $1.73 \pm 1.02$ & $0.87 \pm 0.51$ & 0.001
\end{tabular}

In river region cases $n=6$ station sites $\times 4$ seasons; in lake region cases $n=5$ station sites $\times 4$ seasons. 
dorrii, Schmackeria forbesi, Heterocope appendiculata, Limnoithona sinensis, Mesocyclops leuckarti, Thermocyclops taihokuensis) were present in all six sites. In the lake region, a total of 22 species of crustacean zooplankton were collected, including 10 species of cladocera (38.46\%; belonging to 9 genera) and 5 species of calanoida (22.73\%; belonging to 4 genera) as well as 7 species of cyclopoida (31.82\%; belonging to 7 genera); and 6 species (B. fatalis, B. deitersi, S. dorrii, H. appendiculata, P. fimbriatus, T. taihokuensis) appeared in all five sites (Tab. 3).

\section{Abundance and relative abundance of crustacean}

The abundance of cladocerans, calanoids, cyclopoids and total crustacean in the river region were higher than those in the lake region, and the cladocerans, cyclopoids and total crustacean showed significant difference between the river and lake regions $(\mathrm{P}<0.05)$ (Fig. 2). The relative abundance for $B$. fatalis and calanoids in the river region $(53.22 \%$ and $6.83 \%)$ was lower than that of the lake region $(62.40 \%$ and $9.33 \%)$, but the relative abundance for other cladocera and cyclopoids in the river region $(24.10 \%$ and $16.70 \%)$ was higher than that in the lake region (4.55\% and $12.25 \%$ ), respectively (Fig. 3).

\section{Cluster analysis}

Cluster analysis revealed that crustacean assemblages could be divided into two groups. Cluster A consisted of six sites mainly located on the southern side, i.e., the river region of Lake Gaoyou. Cluster B consisted of five other sites located on the northern side, i.e., the lake region of Lake Gaoyou (Fig. 4).

\section{Correlation analysis}

Correlation analysis indicated that cladoceran, calanoid, cyclopoid and crustaceran abundance was positively correlated with WT and Chl $a$, and negatively correlated with DO. Meanwhile, cladoceran, calanoid and crustaceran abundance were positively correlated with $\mathrm{TN}$ (Tab. 4).

\section{Redundancy analysis}

Detrended correspondence analyses (DCA) of the species data indicated that the first gradient length was

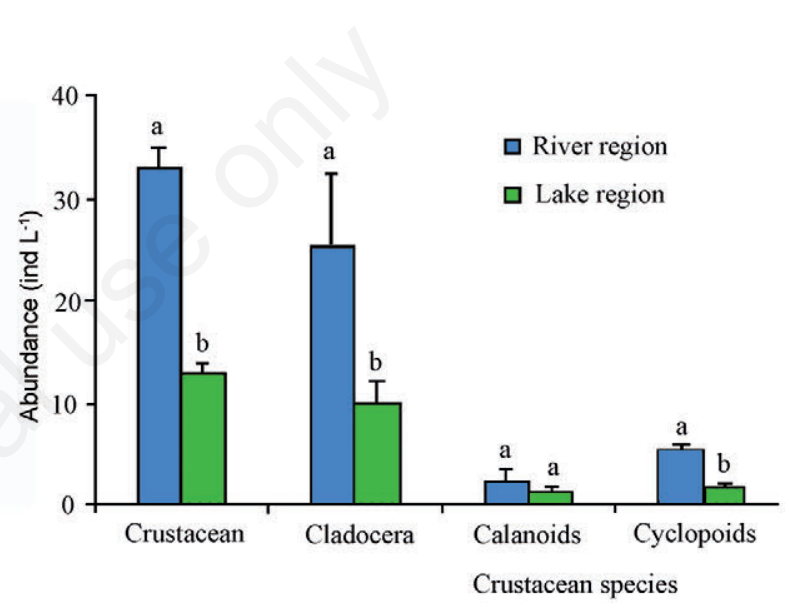

Fig. 2. The crustacean abundance of the river and lake region in Lake Gaoyou. In river region cases $n=6$ station sites $\times 4$ seasons; in lake region cases $n=5$ station sites $\times 4$ seasons; $a$ and $b$ means $\mathrm{P}<0.05$, whereas a and a means $\mathrm{P}>0.05$.

Tab. 2. The species of fishes in Lake and River region.

\begin{tabular}{|c|c|c|c|c|}
\hline & \multicolumn{2}{|c|}{ River region $\left(\mathrm{ha}^{-1}\right)$} & \multicolumn{2}{|c|}{ Lake region $\left(\mathrm{ha}^{-1}\right)$} \\
\hline & Abundance (ind) & Yield (kg) & Abundance (ind) & Yield (kg) \\
\hline Carassius auratus & 2058.6 & 50.4 & 4852.8 & 97.0 \\
\hline Cultrichthys erythropterus & 960.9 & 9.0 & 3421.4 & 48.1 \\
\hline Erythroculter ilishaeformis & 147.6 & 8.4 & 136.2 & 10.9 \\
\hline Pseudorasbora parva & 53.1 & 3.1 & 126.8 & 0.7 \\
\hline Channa argus & 46.5 & 17.7 & 70.3 & 20.5 \\
\hline Hemiculter leucisculus & 41.4 & 1.0 & 2472.0 & 14.2 \\
\hline Cyprinus carpio & 23.4 & 29.9 & 18.0 & 29.3 \\
\hline Acheilognathus macropterus & 10.4 & 0.05 & - & - \\
\hline Pelteobagrus fulvidraco & 7.5 & 0.4 & - & - \\
\hline Coilia nasus & 1.2 & 0.05 & - & - \\
\hline Protosalanx hyalocranius & 1.2 & 0.03 & - & - \\
\hline Hyporhamphus intermedius & 51.6 & 0.2 & - & - \\
\hline Total & 3403.7 & 121.3 & 11097.4 & 220.7 \\
\hline
\end{tabular}


relatively short (2.406), and thus linear-ordination methods were as appropriate as redundancy analysis (RDA). RDA was performed on the whole environmental and species datasets. Results showed that the eigenvalues for RDA axes $1(0.337)$ and 2(0.014) account for $35.1 \%$ of the variance in the species. Forward selection and Monte Carlo simulations indicated that 2 environmental factors (WT and Chl $a$ ) out of the total 7 variables made independent and significant contributions to the variance in abundance of the crustacean assemblages $(\mathrm{P}<0.01)$. Variability in species data was explained by WT $(33.80 \%)$, Chl $a(23.94 \%$ ) (Tab. 5). All crustacean zooplankton were positively correlated with WT, Chl $a$ gradient (Tab. 5 and Fig. 5).

\section{DISCUSSION}

The difference of physicochemical parameters was influenced by macrophytes and hydrodynamic conditions. Macrophytes can significantly enhance water residence time, and nitrogen and phosphorus were retained by increasing deposition of particulate organic matter (Schulz et al., 2003). Allelochemicals released by submerged macrophytes can also inhibit growth of phytoplankton and contribute to the stabilisation of clear-water states in shallow lakes (Hilta and Gross, 2008). Our results are consistent with previous studies that TN and TP in the lake

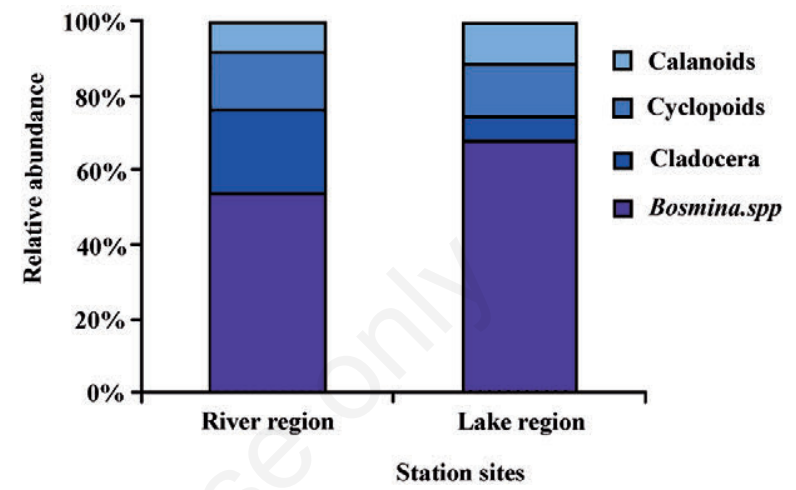

Fig. 3. The relative abundance of crustacean in the river and lake regions in Lake Gaoyou.

Tab. 3. Composition, distribution and occurrence frequency of crustacean zooplankton in Lake Gaoyou.

\begin{tabular}{|c|c|c|c|c|c|}
\hline \multirow[t]{2}{*}{ Code } & \multirow[t]{2}{*}{ Species } & \multicolumn{2}{|c|}{ River region } & \multicolumn{2}{|c|}{ Lake region } \\
\hline & & Emerged station & Occurrence frequency (\%) & Emerged station & Occurrence frequency (\%) \\
\hline & Cladocera & & & & \\
\hline 1 & Diaphanosoma brachyurum & $\mathrm{s} 1 ; \mathrm{s} 2 ; \mathrm{s} 4 ; \mathrm{s} 5 ; \mathrm{s} 6$ & 83.3 & s10;s11 & 40.0 \\
\hline 2 & D.leuchtenbergianum & $\mathrm{s} 1 ; \mathrm{s} 2 ; \mathrm{s} 3 ; \mathrm{s} 4 ; \mathrm{s} 5 ; \mathrm{s} 6$ & 100.0 & s10 & 20.0 \\
\hline 3 & Chydorus ovalis & s2;s3;s4; & 50.0 & s8 & 20.0 \\
\hline 4 & Alona quadrangularis & $\mathrm{s} 1 ; \mathrm{s} 3$ & 33.3 & s8;s10 & 40.0 \\
\hline 5 & Bosmina.fatalis & $\mathrm{s} 1 ; \mathrm{s} 2 ; \mathrm{s} 3 ; \mathrm{s} 4 ; \mathrm{s} 5 ; \mathrm{s} 6$ & 100.0 & $\mathrm{~s} 7 ; \mathrm{s} 8 ; \mathrm{s} 9 ; \mathrm{s} 10 ; \mathrm{s} 11$ & 100.0 \\
\hline 6 & Bosminopsis deitersi & $\mathrm{s} 1 ; \mathrm{s} 2 ; \mathrm{s} 3 ; \mathrm{s} 4 ; \mathrm{s} 5 ; \mathrm{s} 6$ & 100.0 & s7;s8;s9;s10;s11 & 100.0 \\
\hline 7 & Scapholeberis mucronata & s3;s4 & 33.3 & $\mathrm{~s} 7 ; \mathrm{s} 8 ; \mathrm{s} 9 ; \mathrm{s} 10$ & 80.0 \\
\hline 8 & Daphnia psittacea & s3;s6 & 33.3 & - & 0 \\
\hline 9 & D.cucullata & s2;s3;s4;s5;s6 & 83.3 & s9 & 20.0 \\
\hline 10 & Simocephlaus vetulus & $\mathrm{s} 1 ; \mathrm{s} 2 ; \mathrm{s} 3 ; \mathrm{s} 4$ & 66.7 & s7 & 20.0 \\
\hline 11 & Ceriodaphnia cornuta & $\mathrm{s} 2 ; \mathrm{s} 3 ; \mathrm{s} 4 ; \mathrm{s} 5 ; \mathrm{s} 6$ & 83.3 & s7 & 20.0 \\
\hline 12 & C.quadrangula & $\mathrm{s} 1 ; \mathrm{s} 3$ & 33.3 & - & 0 \\
\hline 13 & Moina micrura & $\mathrm{s} 1 ; \mathrm{s} 2 ; \mathrm{s} 3 ; \mathrm{s} 4 ; \mathrm{s} 5 ; \mathrm{s} 6$ & 100.0 & - & 0 \\
\hline \multirow[t]{2}{*}{14} & M. macrocopa & $\mathrm{s} 1 ; \mathrm{s} 2 ; \mathrm{s} 3 ; \mathrm{s} 6$ & 66.7 & - & 0 \\
\hline & Calanoida & & & & \\
\hline 15 & Sinocalanus dorrii & $\mathrm{s} 1 ; \mathrm{s} 2 ; \mathrm{s} 3 ; \mathrm{s} 4 ; \mathrm{s} 5 ; \mathrm{s} 6$ & 100.0 & $\mathrm{~s} 7 ; \mathrm{s} 8 ; \mathrm{s} 9 ; \mathrm{s} 10 ; \mathrm{s} 11$ & 100.0 \\
\hline 16 & Schmackeria inopinus & $\mathrm{s} 1 ; \mathrm{s} 3 ; \mathrm{s} 4 ; \mathrm{s} 5 ; \mathrm{s} 6$ & 83.3 & s7 & 20.0 \\
\hline 17 & Schmackeria forbesi & $\mathrm{s} 1 ; \mathrm{s} 2 ; \mathrm{s} 3 ; \mathrm{s} 4 ; \mathrm{s} 5 ; \mathrm{s} 6$ & 100.0 & s7;s8;s10;s11 & 80.0 \\
\hline 18 & Heterocope appendiculata & $\mathrm{s} 1 ; \mathrm{s} 2 ; \mathrm{s} 3 ; \mathrm{s} 4 ; \mathrm{s} 5 ; \mathrm{s} 6$ & 100.0 & $\mathrm{~s} 7 ; \mathrm{s} 8 ; \mathrm{s} 9 ; \mathrm{s} 10 ; \mathrm{s} 11$ & 100.0 \\
\hline \multirow[t]{2}{*}{19} & Neutrodiaptomus incongruens & $\mathrm{s} 3 ; \mathrm{s} 4 ; \mathrm{s} 5 ; \mathrm{s} 6$ & 66.7 & $\mathrm{~s} 7 ; \mathrm{s} 10$ & 40.0 \\
\hline & Cyclopoida & & & & \\
\hline 20 & Limnoithona sinensis & $\mathrm{s} 1 ; \mathrm{s} 2 ; \mathrm{s} 3 ; \mathrm{s} 4 ; \mathrm{s} 5 ; \mathrm{s} 6$ & 100.0 & s10;s11 & 40.0 \\
\hline 21 & Tropocyclops prasinus & $\mathrm{s} 2 ; \mathrm{s} 3$ & 33.3 & s8 & 20.0 \\
\hline 22 & Paracyclops fimbriatus & $\mathrm{s} 1 ; \mathrm{s} 2 ; \mathrm{s} 3 ; \mathrm{s} 4 ; \mathrm{s} 5$ & 83.3 & $\mathrm{~s} 7 ; \mathrm{s} 8 ; \mathrm{s} 9 ; \mathrm{s} 10 ; \mathrm{s} 11$ & 100.0 \\
\hline 23 & Cyclops vicinus & s3 & 16.7 & s8 & 20.0 \\
\hline 24 & Mesocyclops leuckarti & $\mathrm{s} 1 ; \mathrm{s} 2 ; \mathrm{s} 3 ; \mathrm{s} 4 ; \mathrm{s} 5 ; \mathrm{s} 6$ & 100.0 & s7;s10;s11 & 60.0 \\
\hline 25 & Thermocyclops taihokuensis & $\mathrm{s} 1 ; \mathrm{s} 2 ; \mathrm{s} 3 ; \mathrm{s} 4 ; \mathrm{s} 5 ; \mathrm{s} 6$ & 100.0 & s7;s8;s9;s10;s11 & 100.0 \\
\hline 26 & Microcyclops varicans & $\mathrm{s} 4 ; \mathrm{s} 5 ; \mathrm{s} 6$ & 50.0 & s8 & 20.0 \\
\hline
\end{tabular}


region were lower than that of the river region, but water transparency had an opposite pattern. Hydrodynamic conditions are important factors for planktonic algae growth. The algae abundance under weak water flow was usually higher, and $0.04 \mathrm{~ms}^{-1}$ or so was considered to be the optimal velocity for algae growth because water movement brings new resource for propagation and growth of algae (Hilton et al., 2006; Long et al., 2011). Water from the Huai river flows from the river region of Lake Gaoyou, the velocity was lower than $0.02 \mathrm{~ms}^{-1}$ (Zhang and Zhou, 2009), which may lead to higher phytoplankton abundance, e.g., higher $\mathrm{Chl} a$ concentration in the river region than the lake region.

Transparency and Chl $a$ concentration have become the best measure of trophic status (Carlson, 1977), because transparency can provide an estimator of the volume of the phytoplankton biomass (Wu et al., 2015) and Chl $a$ can measure algal abundance (Rosa and Michelle, 2007). Total nitrogen $(\mathrm{N})$ was also the one of index "trophic status", because nitrogen $(\mathrm{N})$, needed for protein synthesis, was important nutritional element to satisfy phytoplankton growth and was the key limiting nutrients in most aquatic waterbodies (Conley et al., 2009). The lower transparency and higher $\mathrm{Chl} a$ and TN showed trophic status in the river region was higher than that in the lake region (Tab. 1).

In general, fish assemblages in most subtropical lakes are dominated by small omnivorous fish and zooplanktivory is high (Kruk et al., 2009; Lazzaro, 1997). Fishes in lake Gaoyou mainly composed of C. auratus, C. erythropterus and $H$. leucisculus with average weight of $0.021 \mathrm{~kg}^{-1} \mathrm{in}^{-1}, 0.013 \mathrm{~kg}^{\mathrm{ind}} \mathrm{d}^{-1}$ and $0.006 \mathrm{~kg} \mathrm{ind}^{-1}$. Aquatic plants play a vital role in affecting the spatial distribution of aquatic organisms and shaping predator-prey interactions in shallow lakes (Meerhoff et al., 2007). Zooplanktivorous fish aggregate among aquatic plants that offer shelter against piscivorous fish and birds (GonzálezSagrario and Balseiro, 2010). In Lake Gaoyou, only sporadic $M$. spicatum interspersed in the river region, but $T$. incisa paved in the lake region. The relatively difference of fish abundance species and yields existed between the river and lake region, C. auratus, C. erythropterus and $E$. ilishaeformis were the three dominant species in the river region with abundance of 2058.6 ind $\mathrm{ha}^{-1}, 960.9$ ind ha ${ }^{-1}$ and 147.6 ind ha ${ }^{-1}$, but the three dominant species in the lake region was $C$. auratus, C. erythropterus and H. leucisculus with abundance of 4852.8 ind ha ${ }^{-1}, 3421.4$ ind $\mathrm{ha}^{-1}$ and 2472.0 ind ha ${ }^{-1}$.

From Pearson's Correlation Analysis and canonical analysis, the distribution of crustacean zooplankton in the Lake Gaoyou were positively correlated with WT and Chl $a$ gradient. Temperature is recognized as an important structuring factor for the crustacean zooplankton composition in natural lakes because temperature controls feeding, respiration, egg production rates and other metabolic processes (Moore et al., 1996). The crustacean abundance in the river region was higher than one of the lake region $(\mathrm{P}<0.05)$. Many previous studies indicated most nutrientenriched waterbodies were characteristic of an increase



Fig. 4. Hierarchical cluster analysis of crustacean at 11 sampling points in Lake Gaoyou (group-average linkage method using Bray-Curtis similarities). The location for each station refers to Fig. 1B.

Tab. 4. Values for Pearson's correlations of zooplankton abundance and physiochemical parameters.

\begin{tabular}{|c|c|c|c|c|}
\hline & Cladoceran & Calanoid & Cyclopoid & Crustaceran \\
\hline Water temperature & $0.554 * *$ & $0.429 * *$ & $0.619 * *$ & $0.606 * *$ \\
\hline Dissolved oxygen & $-0.449 * *$ & $-.446 * *$ & $-.386^{*}$ & $-.472 * *$ \\
\hline $\mathrm{pH}$ & -0.001 & -0.034 & -0.2 & -0.049 \\
\hline Transparency & -0.238 & -0.196 & -0.158 & -0.237 \\
\hline Total nitrogen & $0.377^{*}$ & $0.318^{*}$ & 0.23 & $0.371 *$ \\
\hline Total phosphorus & 0.023 & -0.04 & 0.025 & 0.021 \\
\hline Chl $a$ & $0.496 * *$ & $0.532 * *$ & $0.479 * *$ & $0.537 * *$ \\
\hline
\end{tabular}

$* P<0.05$; ** $P<0.01$. 
of primary production as zooplankton populations relied on phytoplankton as a food source, which resulted in an increase of zooplankton abundance (Hulyal and Kaliwal, 2008; Larson et al., 2006).

Meanwhile, the crustacean zooplankton structure did change with the changes of trophic status over the waterbodies. In our study, the relative abundance for cyclopoids and cladocera in the river region was higher than that in the lake region respectively, and the relative abundance for calanoids and $B$. fatalis in the river region were lower than that in the lake region (Fig. 3). In general, calanoida (principally herbivorous-filter feeding habit of most species), occur mainly in more oligotrophic waterbodies, where there is a predominance of nanophytoplankton, whereas the cyclopoida occurs at higher abundance under more eutrophic status, owing to their ability to grip larger food particles and prey on smaller species of rotifera and cladocera (Pace, 1986; Santos-Wisniewski and Rocha, 2007).

The eigenvalues for RDA axes express only $35.1 \%$ of the variance of crustacean, the fish can also effect the distribution of crustacean community. The abundance of zooplankton is largely determined by predation pressure, because they are available food of zooplanktivorous fish. It was reported that macrophytes can help zooplankton as refugees escaping from predation by zooplanktivorous fish (Basu et al., 2000). But, aquatic plants are obviously not an efficient daylight refuge for zooplankton, as fish abundance is high among the plants in subtropical lakes (Meerhoff et al., 2007). The result that the abundance of crustacean in the river region were higher than those in the lake region showed aquatic plants had not shelter zooplankton from zooplanktivorous fish. Predation by zooplanktivorous fishes can also be a important factor structuring zooplankton composition. Zooplankton com-

Tab. 5. Environmental variables identified by RDA with forward selection and Monte Carlo permutation tests explaining the significant proportions of variance in crustacean species-environment relationship in Lake Gaoyou.

\begin{tabular}{lcc} 
Variables & Eigenvalues & Variance explained \\
Water temperature** & 0.24 & 33.80 \\
\hline Chl $a^{* *}$ & 0.17 & 23.94 \\
\hline Dissolved oxygen & 0.17 & 23.94 \\
\hline Total nitrogen & 0.07 & 9.86 \\
\hline Transparency & 0.03 & 4.23 \\
\hline $\mathrm{pH}$ & 0.02 & 2.82 \\
\hline Total phosphorus & 0.01 & 1.41 \\
\hline Total & & 100.0 \\
\hline$* * P<0.01$. &
\end{tabular}

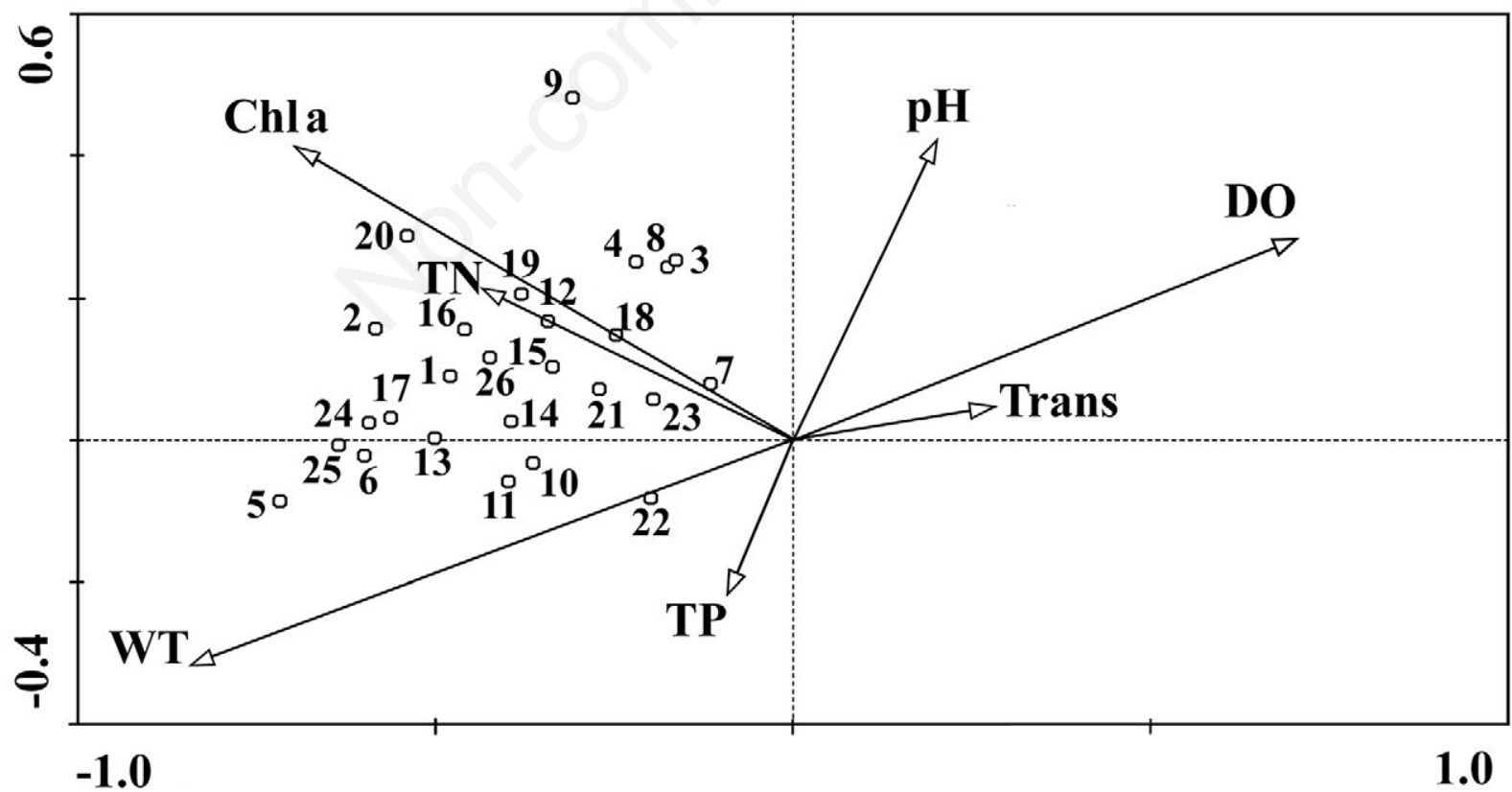

Fig. 5. RDA biplot of crustacean species and environmental variables in Lake Gaoyou. 1, D. brachyurum; 2, D. leuchtenbergianum; 3 , C. ovalis; 4, A. quadrangularis; 5, B. fatalis; 6, B. deitersi; 7, S. mucronata; 8, D. psittacea; 9, D. cucullata; 10, S. vetulus; 11, C. cornuta; 12, C. quadrangula; 13, M. micrura; 14, M. macrocopa; 15, S. dorrii; 16, S. inopinus; 17, S. forbesi; 18, H. appendiculata; 19, N. incongruens; 20, L. sinensis; 21, T. prasinus; 22, P. fimbriatus; 23, C. vicinus; 24, M. leuckarti; 25, T. taihokuensis; 26, M. varicans; WT, water temperature, DO, dissolved oxygen; TP, total phosphorus; TN, total nitrogen. 
munities subjected to fish predation are dominated by small bodied species (e.g., Bosmina), because zooplanktivorous fishes predate preferentially some cladoceran species (e.g., Daphnia) with large-bodied and slowly escape ability. Whereas copepods have been found to be lesser preferred prey than cladocerans, probably owing to faster swimming speeds and greater escape reply (Bourdeau et al., 2015; Kiørboe, 2011).

\section{CONCLUSIONS}

Lake Gaoyou, a large river-connected lake, has obvious river and lake region. Higher abundance of crustacean zooplankton, higher relative abundance for cladocera and cyclopoids and lower relative abundance for calanoids in the river region than that in the lake region may attribute to difference in eutrophic status and fish abundance.

\section{ACKNOWLEDGMENTS}

This research was funded by Aquaculture Sanxin Project of Jiangsu Province (Y2014-28) and the Priority Academic Program Development of Jiangsu Higher Education Institutions grant to FL.

\section{REFERENCES}

Alexander ML, Hotchkiss SC, 2010. Bosmina remains in lake sediment as indicators of zooplankton community composition. J. Paleolimnol. 43:51-59.

Basu BK, Kalff J, Pinel Alloul B, 2000. The influence of macrophyte beds on plankton communities and their export from fluvial lakes in the St Lawrence River. Freshwater Biol. 45:373-382.

Berggren M, Ziegler SE, St-Gelais NF, Beissner BE, Giorgio PA, 2014. Contrasting patterns of allochthony among three major groups of crustacean zooplankton in boreal and temperate lakes. Ecology 95:1947-1959.

Bourdeau PE, Pangle KL, Peacor SD, 2015. Factors affecting the vertical distribution of the zooplankton assemblage in Lake Michigan: The role of the invasive predator Bythotrephes longimanus. J. Great Lakes Res. 41:115-124.

Cairns JJ, McCormick PV, Niederlehner BR, 1993. A proposed framework for developing indicators of ecosystem health. Hydrobiologia 263:1-44.

Carlson RE, 1977. A trophic state index for lakes. Limnol. Oceanogr. 22:361-369.

Chiang SC, Du NS, 1979. [Fauna sinica, crustacea, freshwater cladocera].[Book in Chinese]. Science Press, Beijing.

Conley DJ, Paerl HW, Howarth RW, Boesch DF, Seitzinger SP, Havens KE, Lancelot C, Likens GE, 2009. Controlling eutrophication: nitrogen and phosphorus. Science 323:10141015.

Degefu F, Schagerl M, 2015. Zooplankton abundance, species composition and ecology of tropical high-mountain crater lake Wonchi, Ethiopia. J. Limnol. 74:324-334.
Dodson SI, Lillie RA, Will-Wolf S, 2005. Land use, water chemistry, aquatic vegetation, and zooplankton community structure of shallow lakes. Ecol. Appl. 15:1191-1198.

Dzialowski AR, Bonneau JL, Gemeinhardt TR, 2013. Comparisons of zooplankton and phytoplankton in created shallow water habitats of the lower Missouri River: implications for native fish. Aquat. Ecol. 47:13-24.

Fisher SG, Heffernan JB, Sponseller RA, Welter JR, 2007. Functional ecomorphology: Feedbacks between form and function in fluvial landscape ecosystems. Geomorphology 89:84-96.

González Sagrario MA, Balseiro E, 2010. The role of macroinvertebrates and fish in regulating the provision by macrophytes of refugia for zooplankton in a warm temperate shallow lake. Freshwater Biol. 55:2153-2166.

Guo LG, Wang Q, Xie P, Tao M, Zhang J, Niu Y, Ma ZM, 2015. A non-classical biomanipulation experiment in Gonghu Bay of Lake Taihu: control of microcystis blooms using silver and bighead carp. Aquat. Res. 46:2211-2224.

Hilt S, Gross EM, 2008. Can allelopathically active submerged macrophytes stabilise clear-water states in shallow lakes? Basic Appl. Ecol. 9:422-432.

Hilton J, O'Hare M, Bowes MJ, Jones JI, 2006. How green is my river? A new paradigm of eutrophication in rivers. Sci. Total Environ. 365:66-83.

Hulot FD, Lacroix G, Lescher-Moutoué F, Loreau M, 2000. Functional diversity governs ecosystem response to nutrient enrichment. Nature 405:340-344.

Hulyal SB, Kaliwal BB, 2008. Water quality assessment of Almatti Reservoir of Bijapur (Karnataka State, India) with special reference to zooplankton. Environ. Monit. Asses. 139:299-306.

Jin XC, Tu QY, 1990. [The standard methods for observation and analysis in lake eutrophication].[Book in Chinese]. Chinese Environmental Science Press, Beijing.

Kiørboe T, 2011. What makes pelagic copepods so successful? J. Plankton Res. 33:677-685.

Kruk C, Rodríguez Gallego L, Meerhoff M, Quintans F, Lacerot G, Mazzeo N, Scasso F, Paggi J, Peeters E, Scheffer M, 2009. Determinants of biodiversity in subtropical shallow lakes (Atlantic coast, Uruguay). Freshwater Biol. 54:26282641.

Larson DW, Sweet J, Petersen RR, Crisafulli CM, 2006. Posteruption response of phytoplankton and zooplankton communities in Spirit Lake, Mount St. Helens, Washington. Lake Reserv. Manage. 22:273-292.

Lazzaro X, 1997. Do the trophic cascade hypothesis and classical biomanipulation approaches apply to tropical lakes and reservoirs? Verh. Int. Ver. Limnol. 26:719-730.

Li SH, Fu GH, Guo W, He HC, Zhang ZK, 2007. Environmental changes during modern period from the record of Gaoyou Lake sediments, Jiangsu. J. Geogr. Sci. 17:62-72.

Liu X, Li YL, Liu BG, Qian KM, Chen YW, Gao JF, 2016. Cyanobacteria in the complex river-connected Poyang Lake: horizontal distribution and transport. Hydrobiologia 768: 95-110.

Long TY, Wu L, Meng GH, Guo WH, 2011. Numerical simulation for impacts of hydrodynamic conditions on algae growth in Chongqing section of Jialing River, China. Ecol. Model. 222:112-119. 
Meerhoff M, Iglesias C, De Mello FT, Clemente JM, Jensen E, Lauridsen TL, Jeppesen E, 2007. Effects of habitat complexity on community structure and predator avoidance behaviour of littoral zooplankton in temperate versus subtropical shallow lakes. Freshwater Biol. 52:1009-1021.

Moore MV, Folt CL, Stemberger RS, 1996. Consequences of elevated temperature for zooplankton assemblages in temperate lakes. Arch. Hydrobiol. 135:289-319.

Nanami A, Saito H, Akita T, Motomatsu K, Kuwahara H, 2005. Spatial distribution and assemblage structure of macrobenthic invertebrates in a brackish lake in relation to environmental variables. Estuar. Coast Shelf Sci. 63:167-176.

Pace ML, 1986. An empirical analysis of zooplankton community size structure across lake trophic gradients. Limnol. Oceanogr. 31:45-55.

Pinto Coelho R, Pinel-Alloul B, Méthot G, Havens KE, 2005. Crustacean zooplankton in lakes and reservoirs of temperate and tropical regions: variation with trophic status. Can. J. Fish Aquat. Sci. 62:348-361.

Ren RL, Liu MS, Zhang JM, Zhang M, Xu M, 2007. [Self-purification ability of a water-carrying lake].[Article in Chinese]. Chin. J. Ecol. 26:1222-1227.

Rosa G-C, Michelle S, 2007. Trophic status evaluation for 154 lakes in Quebec, Canada: monitoring and recommendations. Water Qual. Res. J. Can. 42:252-268.

Santos Wisniewski MJ, Rocha O, 2007. Spatial distribution and secondary production of copepoda in a tropical reservoir: Barra Bonita, SP, Brazil. Braz. J. Biol. 67:223-233.

Sarma SSS, Nandini S, Morales-Ventura J, Delgado-Martínez I,
González-Valverde L, 2006. Effects of $\mathrm{NaCl}$ salinity on the population dynamics of freshwater zooplankton (rotifers and cladocerans). Aquat. Ecol. 40:349-360.

Schulz M, Kozerski HP, Pluntke T, Rinke K, 2003. The influence of macrophytes on sedimentation and nutrient retention in the lower River Spree (Germany). Water Res. 37:569-578.

ter Braak C, Šmilauer P, 2002. CANOCO ver. 4.5. Biometris Plant Research Int., Wageningen, The Netherlands.

Wang H, Zhou YY, Tang Y, Wu MG, Deng YQ, 2015. Fluctuation of the water environmental carrying capacity in a huge river-connected lake. Int. J. Environ. Res. Public Health 12:3564-3578.

Wang HZ, Xu QQ, Cui YD, Liang YL, 2007. Macrozoobenthic community of Poyang Lake, the largest freshwater lake of China, in the Yangtze floodplain. Limnology 8:65-71.

Wu ZX, Zhang YL, Zhou YQ, Liu ML, Shi K, Yu ZM, 2015. Seasonal-spatial distribution and long-term variation of transparency in Xin'anjiang Reservoir: Implications for reservoir management. Int. J. Environ. Res. Public Health 12:9492-9507.

Yang JF, Lei K, Khu S, Meng W, Qiao F, 2015. Assessment of water environmental carrying capacity for sustainable development using a coupled system dynamics approach applied to the Tieling of the Liao River Basin, China. Environ. Earth Sci. 73:5173-5183.

Zhang W, Zhou XQ, 2009. [Studies on the normal flood channel in conservation planning of lakes - the determination of flood channel by hydraulic calculation in Lake Gaoyou].[Article in Chinese]. Water Res. Plann. Design 5:16-18. 